\title{
PROGRAMME OF SESSIONS
}

Sunday, 19 August 2001

OPENING OF SYMPOSIUM:

0900-0930 h

W. Dansgaard: The oldest news
Robert A. Bindschadler, President, International Glaciological Society Dorthe Dahl-Jensen, Head of Local Organizing Committee Eric W. Wolff, Chief Editor

0910-1030h

Session 1: Late QUATERnary Glimate from ICE Gores, 1: Greenland Glimate of the LaSt 150000 Years

Dorthe Dahl-Jensen, Niels S. Gundestrup, Heinz Miller, Okitsugu Watanabe, SigfúsJ. Johnsen, Jørgen P. Steffensen, Henrik B. Clausen, Anders Svensson and Lars B. Larsen: The NorthGRIP deep drilling programme

Sune Olander Rasmussen, Katrine Krogh Andersen, Marie-Louise Siggaard-Andersen and Henrik B. Clausen: Extracting the annual signal from Greenland ice-core chemistry and isotopic records

Thorsteinn Thorsteinsson, Yun Wang, Josef Kipfstuhl, Heinz Miller and Hitoshi Shoji: The normal grain-growth regime in the NGRIP deep ice core compared with other Greenland locations

Jørgen Peder Steffensen and Dorthe Dahl-Jensen: An attempt to understand some of the chemical profiles of the Eemian and deeper ice in the GRIP core

Niels Reeh, Hans Oerter and Henrik Højmark Thomsen: Comparison between Greenland ice-margin and ice-core oxygen18 records

Roy M. Koerner and David A. Fisher: Ice-core evidence for widespread Arctic glacier retreat in the Last Interglacial and the early Holocene

$1310-1510 h$

CHAIR: Mary R. Albert

SESSION 2: IMPROVING ICE-CORE INTERPRETATION THROUGH METEOROLOGY, MODELLING AND AIR-SNOW TRANSFER STUDIES

C. H. Reijmer, M. R. van den Broeke and M. P. Scheele: Air parcel trajectories to five deep drilling locations on Antarctica, based on the ERA-15 dataset

Jonathan D.W. Kahl: Atmospheric transport to Summit, Greenland: changes during the past four decades

G. Krinner and G. Genthon: Modelled air mass transport times from remote source regions to ice core drilling sites at the LGM compared to today

Martin Werner, Ina Tegen, Caroline Roelandt, Karen Kohfeld, Yves Balkanski, Margareta Hansson, Sandy Harrison, Colin Prentice, Michael Schulz, Claudia Timmreck and Henning Rodhe: Mineral dust in polar ice cores: a model study of present and glacial sources, transport and deposition

Alexey A. Ekaykin, Vladimir Ya. Lipenkov, Narcisse I. Barkov, Jean Robert Petit and Valerie Masson-Delmotte: Spatial and temporal variability in isotope composition of recent snow in the vicinity of Vostok Station, Antarctica: implications for ice-core record interpretation

Jeffrey L. Kavanaugh and Kurt M. Guffey: Generalized view of source-region effects on $\delta \mathrm{D}$ and deuterium excess in ice-sheet precipitation

$1530-1800 \mathrm{~h}$

CHAIR: Konrad Steffen

Sigfús J. Johnsen, James White, Arny E. Sveinbjörnsdóttir, Niels Gundestrup, Georg Hoffmann and Timothy Creyts: Diffusion of stable isotopes in Greenland firn and ice used to constrain palaeotemperatures and diffusivities in solid ice

Edwin D. Waddington, Eric J. Steig and Thomas A. Neumann: Using characteristic times to assess whether stable isotopes in polar snow can be reversibly deposited

R. Udisti, S. Becagli, O. Largiuni, R. Traversi, R. Mulvaney, E. Wolff, R. Röthlisberger and R. Delmas: Evidence of postdepositional processes in superficial and deep layers in EPICA-Dome $\mathrm{C}$ ice core

Manuel A. Hutterli, Joseph R. McConnell and Roger C. Bales: Increase of HCHO and $\mathrm{H}_{2} \mathrm{O}_{2}$ in Greenland firn: to what extent an effect of changes in accumulation timing?

Mark A. J. Curran, Anne S. Palmer, Tas D. van Ommen, Vin Morgan, Katrina L. Phillips, Alison J. McMorrow and Paul A. Mayewski: Post-depositional movement of methanesulphonic acid at Law Dome and the effect on accumulation rate

Peter D. Ditlevsen, Susanne Ditlevsen and Katrine K. Andersen: The fast climate fluctuations during the stadial and interstadial climate states 
Mary R. Albert and Robert L. Hawley: Seasonal changes in snow surface roughness characteristics at Summit, Greenland: implications for snow and firn ventilation

Monday, 20 August 2001

0830-1100 h

CHAIR: Yao Tandong

\section{Session 3: Glimate and Ghange in the Past Two Millennia, 1}

Nancy Bertler, Peter Barrett, Paul A. Mayewski, Warren Dickinson, Alex Pyne and Jamie Shulmeister: Holocene climate record from the Dry Valleys, Antarctica: initial results for the last 650 years

Kumiko Goto-Azuma, Roy M. Koerner and David A. Fisher: An ice-core record over the last two centuries from Penny Ice Cap, Baffin Island, Canada

Qin Dahe, Hou Shugui, Zhang Dongqi, RenJiawen, Kang Shichang, Paul A. Mayewski and Cameron P. Wake: Preliminary results from the chemical records of an $80.4 \mathrm{~m}$ ice core recovered from the East Rongbuk Glacier, Mt Qomolangma (Everest)

Patrick Ginot, Margit Schwikowski, Ulrich Schotterer, Willibald Stichler, Heinz W. Gäggeler, Bernard Francou, Robert Gallaire and Bernard Pouyaud: Climate variability reconstruction from Andean glaciochemical records

Teija Kekonen, John Moore, Robert Mulvaney, Elisabeth Isaksson, Veijo Pohjola and Roderik S. W. van de Wal: An 800 year record of nitrate from the Lomonosovfonna ice core, Svalbard

$0830-1100 \mathrm{~h}$

CHAIR: Vincent I. Morgan

John Moore, Teija Kekonen, Robert Mulvaney, Elisabeth Isaksson and Veijo Pohjola: A record of sulphuric acid deposition in a Svalbard ice core spanning the industrial revolution

Sun Junying, Ren Jiawen and Qin Dahe: Sixty-year record of biogenic sulfur from Lambert Glacier basin firn core, East Antarctica

Michel Legrand, Susanne Preunkert and Dietmar Wagenbach: Historical atmospheric sulphate loads at $4300 \mathrm{~m}$ a.s.l. above Europe derived from a high Alpine ice core study and dedicated air/firn relation investigations

Anne S. Palmer, Vin Morgan, Mark A. J. Gurran, Tas D. van Ommen and Paul A. Mayewski: Antarctic volcanic flux ratios from Law Dome ice cores

Wolfgang Graf, Hans Oerter, Oskar Reinwarth, Willibald Stichler, Frank Wilhelms, Heinz Miller and Robert Mulvaney: Stable-isotope records from Dronning Maud Land, Antarctica

\section{$1400-1800 h$}

\section{Poster Session 1}

T. McCormack, R. Mulvaney, C. Arrowsmith, G. Littot and B. Knight: Results from a series of shallow ice cores from Berkner Island, Antarctic

William D. Miners, Eric W. Wolff, Sebastian Gerland: Modelling a radio-echo sounding record using ice core data to produce a synthetic radargram

Anna Grönlund, Douglas Nilsson, Ismo Koponen, Aki Virkkula, Margareta Hansson: Aerosol dry deposition measured with eddy-covariance technique at Wasa, Dronning Maud Land, Antarctica

Yoshiyuki Fujii, Mika Kohno, Kokichi Kamiyama, Hideaki Motoyama, Sumito Matoba, Makoto Igarashi and Okitsugu Watanabe: Microparticle concentration change during past 320 ka recorded in Dome Fuji ice core, Antarctica

Fumihiko Nishio, Teruo Furukawa, G. Hashida, Makoto Igarashi, Takao Kameda, Mika Kohno, Hideaki Motoyama, K. Naoki, Kazuhide Satow, Keisuke Suzuki, Morimasa Takata, Yoko Toyama, T. Yamada and Okitsugu Watanabe: Annual layer determinations and 167 year records of past climate of $\mathrm{H} 72$ ice core in east Dronning Maud Land, Antarctica

Sepp Kipfstuhl and Johannes Freitag: Air bubble studies from the Dome C ice core, Antarctica

RenJiawen, Ian Allison, Qin Dahe and Xiao Cunde: Variability of the accumulation rate and the ice budget over the Lambert Glacier basin, East Antarctica

Elisabeth Isaksson, Jack Kohler, Makoto Igarashi, Lars Karlöf, Teija Kekkonen, Tõnu Martma, Harro Meijer, John Moore, Hideaki Motoyama, Robert Mulvaney and Veijo Pohjola: Climate variability on Svalbard: results from two ice cores

Elisabeth Isaksson and Kjetil Melvold: Trends and patterns in the recent accumulation and oxygen isotopes in coastal Dronning Maud Land, Antarctica: interpretations from shallow ice cores

Alison J. McMorrow, Mark A. J. Curran, Tas D. van Ommen, Vin Morgan and Ian Allison: Features of meteorological events preserved in a high-resolution Law Dome snow pit

Barbara Smith, Tas van Ommen, Vin Morgan. Distribution of oxygen isotope ratios and accumulation rates in Wilhelm II Land, East Antarctica

Xiao Cunde, Ren Jiawen, Qin Dahe et al.: Remarkable difference of climatic variations between the eastern and western sides of Lambert Glacier basin, Antarctica

Elisabeth Schlosser and Hans Oerter: Shallow firn cores from Neumayer, Ekströmisen, Antarctica: a comparison of accumulation rates and stable-isotope ratios

K. A. Kaspers, R. S.W. van de Wal, J. A. de Gouw, C. J. van derVeen, C. A. M. Brenninkmeijer, L. Karlöf and J.-G. Winther: Past atmospheric composition from chemical analyses of firn air from Dronning Maud Land 2000/2001, Antarctica 
Bernd Mügge, Ralf Greve and Kolumban Hutter: Simulation of the Antarctic ice sheet with a three-dimensional polythermal ice sheet model, in support of the EPICA project

Lars Karlöf, Jan-Gunnar Winther, Rickard Pettersson, Gaute Lappegard, Coen Hofstede and Roderik van de Wal: Point accumulation variability in a $8 \times 8 \mathrm{~km}$ area, eastern Dronning Maud Land, Antarctica, as determined from shallow firn cores and snow pits

R. S. W. van de Wal, W. J. M. van der Kemp, K. van der Borg, A. F. M. de Jong, C. Alderliesten, J. Oerlemans, C. van der Veen and R. A. N. Lamers: ${ }^{14}$ C-measurements along the EPICA-Dome C core

Elisabeth Schlosser and Hans Oerter: Seasonality of accumulation and the isotope record in ice cores — a study with surface snow samples and firn cores from Neumayer Station, Antarctica

Elisabeth Schlosser and Hans Oerter: Stable isotopes in the snow and origin of precipitation at Neumayer, Ekströmisen, Antarctica

Martine de Angelis, Ian Goodwin and R. Udisti: Preliminary investigation of light carboxylic acids in ice and firn cores of the East Antarctic Plateau

Gordon Hamilton: Mass balance and accumulation rates across Siple Dome, West Antarctica

Takeo Hondoh, Hitoshi Shoji, Okitsugu Watanabe, Andrey N. Salamatin and Vladimir Ya. Lipenkov: Depth-age and temperature prediction at Dome Fuji station, East Antarctica

C. M. Hofstede, R. S.W. van de Wal, L. Karlöf, J.-G. Winther, E. Isaksson, G. Lappegard and F. Wilhelms: The accumulation record from a medium long ice core in eastern Dronning Maud Land, Antarctica

Rita Traversi, Silvia Becagli, Emiliano Castellano, A. Migliori, M. Severi and Roberto Udisti: Sulphate, chloride and nitrate profiles in the last 50,000 years from EPICA-Dome C ice core

S. Becagli, E. Castellano, R. Traversi, B. Stenni, O. Flora, M. Proposito, R. Gragnani, M. Frezzotti and R. Udisti: Volcanic and biogenic signatures for sulphate and methanesulfonate at Talos Dome (East Antarctica)

Geneviève C. Littot, Robert Mulvaney, Regine Röthlisberger, Roberto Udisti, Eric W. Wolff, Emiliano Castellano, Martine de Angelis, Margareta Hansson, Stefan Sommer and Jørgen P. Steffensen: Comparison of analytical methods used for measuring major ions in the EPICA-Dome $\mathrm{C}$ (Antarctica) ice core

Marco Proposito, Silvia Becagli, Emiliano Castellano, O. Flora, Roberto Gragnani, Barbara Stenni, Rita Traversi, Roberto Udisti and Massimo Frezzotti: Chemical and isotopic snow variability along the 1998 ITASE traverse from Terra Nova Bay to Dome C, East Antarctica

Hou Shugui et al.: Comparison of two ice core chemical records recovered from the Mt Qomolangma (Everest) region

Hou Shugui, Qin Dahe, C. P. Wake and K. Kreutz: Monsoon and dust signals recorded in a $2.5 \mathrm{~m}$ snowpit, Mt Chu Oyu, Nepal Himalayas

Tuesday, 21 August 2001

$0830-1230 h$

CHAIR: Dorthe Dahl-Jensen

Session 4: Late Quaternary Glimate from IGe Cores, 2: ANTARGtic AND Bipolar Glimate and ENvironmENT

E. Castellano, A. Migliori, M. Severi, R. Udisti, C. Hammer, J. P. Steffensen and J. R. Petit: Global volcanism recorded in Antarctic ice sheet: a comparison of signatures from different ice cores

F. Vimeux, V. Masson-Delmotte, G. Delaygue, S. Johnsen, J. Jouzel, J. R. Petit, B. Stenni and M. Stiévenard: Paleoclimatic variations of polar snow deuterium excess: indicator of ocean surface temperature changes

Jefferson C. Simões, Jean Robert Petit, Roland Souchez, Vladimir Ya. Lipenkov, Martine de Angelis, Liu Leibao, Jean Jouzel and Paul Duval: Evidence of glacial flour in the deepest $89 \mathrm{~m}$ of the Vostok ice core

Shuji Fujita, Nobuhiko Azuma, Hideaki Motoyama, Takao Kameda, Hideki Narita, Yoshiyuki Fujii and Okitsugu Watanabe: Electrical measurements on the $2503 \mathrm{~m}$ Dome F Antarctic ice core

B. Stenni, V. Masson-Delmotte, O. Cattani, S. Falourd, S. Johnsen, J. Jouzel, A. Longinelli and E. Selmo: A 44 ka deuterium and deuterium excess records at Dome Concordia (East Antarctica)

Barbara Delmonte, Jean Robert Petit and Valter Maggi: LGM-Holocene changes and Holocene millennial-scale oscillations of dust particles in the EPICA-Dome G ice core, East Antarctica

Regine Röthlisberger, Manuel A. Hutterli, Eric W. Wolff, Robert Mulvaney, Hubertus Fischer, Matthias Bigler, Kumiko Goto-Azuma, Margareta E. Hansson, Urs Ruth, Marie-Louise Siggaard-Andersen and Jørgen P. Steffensen: Nitrate in Greenland and Antarctic ice cores: a detailed description of post-depositional processes

Vin Morgan, Tas D. van Ommen and Suenor Woon: The oxygen isotope record from Law Dome, East Antarctica

Eric W. Wolff and Robert Mulvaney: Ultra-high resolution analysis of the GRIP Greenland ice core

Wednesday, 22 August 2001

0840-0940 h

CHAIR: David A. Fisher

Session 5: MASs Balance of the Greenland ICe Sheet

R. S.W. van de Wal, M. M. Helsen and H. Bartholomeus: An ablation model for the Greenland ice sheet

Waleed Abdalati and PARCA Investigators: Program for Arctic Regional Climate Assessment (PARCA)

Edward Hanna, Philippe Huybrechts and Thomas L. Mote: Surface mass balance of the Greenland ice sheet from climateanalysis data and accumulation/runoff models 


\section{Session 6: Late QuATernary Glimate from ICe Cores, 3: ARGTIC and Bipolar Glimate and ENVIRONMENT}

Bernhard Stauffer, J. Flückiger, Eric Monnin, Jakob Schwander, Jean-Marc Barnola and Jérôme Chappellaz: Atmospheric $\mathrm{CO}_{2}, \mathrm{CH}_{4}$ and $\mathrm{N}_{2} \mathrm{O}$ records over the past 60000 years based on the comparison of different polar ice cores

Christian Zdanowicz, David A. Fisher, I. Clark and D. Lacelle: An ice-marginal $\delta^{18} \mathrm{O}$ record from Barnes Ice Cap, Baffin Island, Canada

Gary D. Clow and Edwin D. Waddington: Reconstructing climatic changes at Summit, Greenland and Taylor Dome, Antarctica using borehole paleothermometry

$1100-1200 h$

CHAIR: Eric W. Wolff

Discussion: Integrity of ice-core records

\section{Session 7: Glimate and Ghange in the Past Two Millennia, 2}

Fidan Göktas, Hubertus Fischer, Hans Oerter, Rolf Weller, Stefan Sommer and Heinz Miller: A glacio-chemical characterization of the new EPICA deep-drilling site on Amundsenisen, Dronning Maud Land, Antarctica

Yao Tandong, Duan Keqin, Xu Baiqing, Wang Ninglian, Pu Jianchen, Kang Shichang, Qin Xiang and Lonnie Thompson: The climatic changes of the past 1000 years recorded in Dasuopu ice core

Yang Meixue, Yao Tandong and He Yuanqing: The significance of the relationship between ENSO events and Guliya ice core records in Tibetan Plateau

Lars Berg Larsen, Marie-Louise Siggaard-Andersen, Henrik B. Clausen and Claus Uffe Hammer: A glacio-chemical analysis of a climatic event

Eric A. Meyerson, Paul A. Mayewski, KarlJ. Kreutz, L. David Meeker, Sallie I. Whitlow and Mark S. Twickler: The polar expression of ENSO and sea-ice variability as recorded in a South Pole ice core

Robert Mulvaney, Hans Oerter, David A. Peel, Wolfgang Graf, Carol Arrowsmith, Elisabeth C. Pasteur, B. Knight, Geneviève C. Littot and William D. Miners: 1000-year ice-core records from Berkner Island, Antarctic

\section{POSTER SESSION 2}

Ingeborg Auer, Reinhard Böhm, Corinna Huhle and Wolfgang Schöner: Precipitation adjusted temperature series — a way to optimise instrumental climate time series for comparisons with stable isotope ice core information from high Alpine sites

Wolfgang Schöner, Ingeborg Auer, Reinhard Böhm, Lothar Keck and Dietmar Wagenbach: Spatial representativity of climate information from instrumental and ice core based Alpine records

Roderik S. W. van de Wal, Robert Mulvaney, Elisabeth Isaksson, John C. Moore, Jean Francis Pinglot, Veijo A. Pohjola and Martijn P. A. Thomassen: Reconstruction of the historical temperature trend from measurements in a medium-length borehole on the Lomonosovfonna plateau, Svalbard

Veijo A. Pohjola, Tõnu A. Martma, Harro A. J. Meijer, John G. Moore, Elisabeth Isaksson, Rein Vaikmäe and Roderik S. W. van de Wal: Reconstruction of 300 years accumulation rates from Lomonosovfonna, Svalbard

Stephan Suter and Martin Hoelzle: Cold firn in the Mont Blanc and Monte Rosa areas, European Alps: spatial distribution and statistical models

L. Keck, S. Preunkert, M. Legrand, M. Leuenberger, R. Böhm and D. Wagenbach: Significance of ice core records from high elevation mountain glaciers

Hans-Arno Synal, Peter Kubik, Jürg Beer, Raimund Muscheler and Gerhard Wagner: Long-lived radionuclides in ice core records: what can we learn

S. Preunkert, M. Legrand and D. Wagenbach: Changes in fluoride and sulfate levels in an Alpine ice core over the 20th century: implications on their atmospheric budgets over Europe

Jari Vehviläinen, Elisabeth Isaksson and John Moore: A 20th-century record of naphthalene in an ice core from Svalbard

Jefferson C. Simões, Francisco A. Ferron, Ronaldo T. Bernardo, Alberto J. Aristarain, Michel Stiévenard, Michel Pourchet and Alexandre L. Correia: Spatial distribution of shallow ice core parameters in the South Shetland Islands

David A. Fisher, Roy M. Koerner, Gregory A. Zielinski, Cameron P. Wake, Christian M. Zdanowicz, Jocelyne C. Bourgeois, Paul A. Mayewski and N. Grummet: The effects of flowline leng th evolution on the chemistry $-\delta^{18}$ O profiles from Penny Ice Cap, Baffin Island, Canada

Cameron P. Wake, Kaplan Yalcin and Niels Gundestrup: The climate signal recorded in the oxygen-isotope, accumulation and major-ion time series from the Eclipse ice core, Yukon Territory, Canada

David L. Naftz, David D. Susong, L. DeWayne Cecil, Paul F. Schuster, Robert L. Michel and Carol Kendall: Development and application of a transfer function between $\delta^{18} \mathrm{O}$ values in snowfall and surface air temperature, Upper Fremont Glacier, Wyoming, U.S.A.

Paul F. Schuster, David P. Krabbenhoft, David L. Naftz, L. DeWayne Cecil, Mark L. Olson, John F. DeWild, David D. Susong and Jaromy R. Green: A 270-year ice core record of atmospheric mercury deposition to western North America 
David D. Susong, Michael Abbott, David L. Naftz, Paul Schuster and L. DeWayne Cecil: Mercury in snow: records of atmospheric mercury deposition from mid-latitude sites in North America and central Asia

L. DeWayne Cecil, Hans-Arno Synal, Jaromy R. Green, Javier Santos, Jürg Beer, David L. Naftz, Karl J. Kreutz, Cameron P. Wake and Vladimir B. Aizen: Radioactive isotope profiles from mid-latitude glaciers.

L. DeWayne Cecil, Jaromy R. Green, David L. Naftz, David D. Susong and Paul F. Schuster: Global environmental change research

T. Shiraiwa, S. Kohshima, R. Uemura, N. Yoshida, S. Matoba, J. Uetake and M. A. Godoi: High net accumulation rates at the Southern Patagonia Icefield revealed by chemical and biological analyses of a 45.97-m-long ice core

G.W. Kent Moore, Keith Alverson and Gerald Holdsworth: Variability in the climate of the Pacific Ocean and North America as expressed in an ice core from Mount Logan

Shuji Fujita, Nobuhiko Azuma, Hideaki Motoyama, Takao Kameda, Hideki Narita, Yoshiyuki Fujii and Okitsugu Watanabe: Linear and non-linear relations between high-frequency-limit conductivity, AC-ECM signals and ECM signals of Dome F Antarctic ice core from a laboratory experiment

H. Shoji, K. Satow, H. Narita, S. Aoki, H. Motoyama, Y. Fujii and O. Watanabe: A depth-age relationship of the Dome Fuji, Antarctica deep ice core

Hiroshi Ohno, Vladimir Ya. Lipenkov and Takeo Hondoh: Number densities of air bubbles and air hydrates in the Dome F ice core

Ted Scambos and Mark Fahnestock: Snow megadunes and the ice core climate record

Todd K. Hinkley and Akikazu Matsumoto: How much dust and how much salt is really in polar ice? Atmospheric regime of dust and salt through 75,000 years of Taylor Dome ice core: refinement by measurement of major, minor and trace metal suites

Weili Wang, Roland C. Warner and William F. Budd: Ice flow properties at Dome Summit South, Law Dome, East Antarctica

He Yuanqing, Wilfred H. Theakstone, Yao Tandong, Zhao Xiaojun and Yang Meixue: The irregular pattern of isotopic and ionic signals in the typical monsoon temperate-glacier area, Yulong mountain, China

Yoko Toyama, Fumihiko Nishio, Takayuki Shiraiwa, Takao Kameda, AkiyoshiTakahashi, NoriyukiTanaka, Yaroslav D. Murav'yev and Alexander A. Ovsyannikov: Dating of Ushkovsky ice cap core in Kamchatka by DC-electrical conductivity measurement method

Karl J. Kreutz, Cameron P. Wake, Vladimir B. Aizen and L. DeWayne Cecil: Spatial and altitudinal variability of precipitation isotopes in the central Tien Shan Mountains

Wang Ninglian, Yao Tandong, Lonnie G. Thompson and Mary E. Davis: Indian monsoon and North Atlantic Oscillation signals reflected by $\mathrm{Cl}^{-}$and $\mathrm{Na}^{+}$in a shallow ice core from Dasuopu glacier, Xixabangma, Himalaya

Takayuki Shiraiwa, Tetsuya Fujikawa, Noriyuki Tanaka, Sumito Matoba, Yaroslav D. Murav'yev, Fumihiko Nishio and Yoko Toyama: A 170-year proxy climate records derived from co-isotopic and chemical analyses of ice core recovered from Ushkovsky ice cap, Kamchatka

Duan Keqin, Yao Tandong, Sun Weizhen and Li Xinqing: Indian monsoon variability in Himalayas since 1800 AD

Duan Keqin, Yao Tandong, Wang Ninglian, Sun Weizhen and Li Xinqing: An examination of possible solar activity effects in the accumulation variability of Dasuopu glacier in Himalayas

Lee Xinqing, Zhou Hui: Oxalate record in ice cores: connection between Glacier 1, Tianshan, China, and Far East Rongbuk Glacier, Everest

Lee Xinqing, Qin Dahe, Hou Shugui, Ren Jiawen, Duan Keqin, Zhou Hui: Changes in chemical and isotopic properties near infiltrated cracks in an ice core from Glacier No.l at Ürümqi riverhead, Tien Shan, China

\section{$1930-2300 h$}

\section{Poster SESSION 3}

Andreas P. Ahlstrøm, Carl Egede Bøggild, Ole B. Olesen, Johan J. Mohr and Maria Plougmann Hag: Ice sheet ablation in the Tasersiaq region of West Greenland determined from in situ observations, satellite images and energy balance modelling

Morimasa Takata, Yoshiyuki Fujii, Hitoshi Shoji, Kimiko Shimohara, Atsushi Miyamoto and Josef Kipfstuhl: Stratigraphy analysis of deep ice cores by a laser tomograph measurement

M.-L. Siggaard-Andersen, C. U. Hammer, A. Murray and N. A. Larsen: Luminescence experiments on mineral dust extracted from the NGRIP deep ice core

Marie-Louise Siggaard-Andersen, Jørgen Peder Steffensen and Hubertus Fischer: Lithium in Greenland ice core samples measured by ion chromatography

Aslak Grinsted and Dorthe Dahl-Jensen: A Monte Carlo-tuned model of the flow in the NorthGRIP area

Philippe Huybrechts, Ives Janssens, Chantal Poncin and Thierry Fichefet: The response of the Greenland ice sheet to climate changes in the 21st century by interactive coupling of an AOGGM with a thermomechanical ice-sheet model

LiJun, Weili Wang and H. Jay Zwally: Interannual variations of shallow firn temperature at Greenland summit

S. H. Faria, D. Ktitarev and K. Hutter: Modelling evolution of anisotropy in fabric and texture of polar ice

Hans Weertman: The Comninou-Dundurs effect and position stability of subglacial lakes

Ralf Greve, YongqiWang and Bernd Mügge: Comparison of numerical schemes for the solution of the advective age equation in ice sheets

Olivier Gagliardini and Jacques Meyssonnier: Lateral boundary conditions for a local anisotropic ice-flow model

Gina L. Luciano and Mary R. Albert: Bidirectional permeability measurements of polar firn

Mary Albert: Effects of snow and firn ventilation on sublimation rates

Gary Koh, Mary R. Albert and Edward F. Shultz: FMCW radar mapping of hoar layers in polar firn 
Piers R. F. Barnes, Robert Mulvaney, K. Robinson and Eric W. Wolff: Observations of polar ice from the Holocene and the glacial period using the scanning electron microscope

Mika Kohno and Yoshiyuki Fujii: Past 220 year bipolar volcanic signals: remarks on common features of their source volcanic eruptions

Annette Hofmann and Sepp Kipfstuhl: Rapid climate oscillations during the last glaciation in the Scotia Sea - on the link between magnetic susceptibility and dust records

Carl Egede Bøggild: Diagnostic model analysis of spatial mass- and energy balance conditions at the Northeast Greenland ice sheet margin

Konrad Steffen, Jason Box and Nicolas Cullen: Radiation climatology of the Greenland ice sheet

David A. Braaten, S. Prasad Gogineni, D. Tammana, S. K. Namburi, John Paden and K. Gurumoorthy: Improvement of radar ice-thickness measurements of Greenland outlet glaciers using SAR processing

Jessica E. Miller, Jonathan D.W. Kahl, Fred Heller and Joyce M. Harris: A three-dimensional residence-time analysis of potential summertime atmospheric transport to Summit, Greenland

Hubertus Fischer and Matthias Schwager: Potential of northern Greenland ice cores for the reconstruction of large scale teleconnection patterns

Gerhard Krinner, Christophe Genthon and Martin Werner: Impact of precipitation seasonality on isotopic signals in ice cores: an analysis of several atmospheric general circulation model simulations

Urs Ruth, Dietmar Wagenbach, Matthias Bigler, Jørgen P. Steffensen, Regine Röthlisberger and Heinz Miller: High-resolution microparticle profiles at NorthGRIP, Greenland: case studies of the calcium-dust relationship

Irene A. Mogensen, SigfúsJ. Johnsen, Andrey Ganoploski and Stefan Rahmstorf: An investigation of rapid warm transitions during MIS2 and MIS3 using Greenland ice-core data and the CLIMBER-2 model

K. M. Hansen, A. Svensson, Y. Wang and J. P. Steffensen: Properties of GRIP ice crystals from around Greenland interstadial 3

Birgit Mieding, Hubertus Fischer, Matthias Bigler, Frank Wilhelms and Sepp Kipfstuhl: Reconstruction of seasonal variations in aerosol transport and deposition from chemical ice core records in Northeast Greenland

Johannes Freitag, Uwe Dobrindt, Sepp Kipfstuhl: A new method for predicting transport properties of polar firn on its pore scale

Filip Lefebre, Hubert Gallée, Jean-Pascal van Ypersele and Philippe Huybrechts: Modelling of large-scale melt parameters with a regional climate model in south Greenland during the 1991 melt season

K. K. Andersen and P. D. Ditlevsen: Noise reduction in ice core records

L. B. Larsen, P. Kanagaratnam, N. Gundestrup, P. Gogineni, H. B. Clausen and J. Legarsky: Accumulation rate at NGRIP determined by radar profiling

L. B. Larsen, J. Legarsky, N. Gundestrup, P. Gogineni, P. Kanagaratnam and T. Atkins: Firn measurements using a Ka-band ranging scatterometer

Christine Schøtt Hvidberg, Jørgen Peder Steffensen, Henrik B. Glausen, Hitoshi Shoji and Josef Kipfstuhl: The NorthGRIP ice-core logging procedure: description and evaluation

C. S. Hvidberg, Kristian Keller, N. Gundestrup: Mass balance and ice flow along the NNW ridge of the Greenland ice sheet at NorthGRIP

Matthias Bigler, Dietmar Wagenbach, Hubertus Fischer, Sepp Kipfstuhl, Heinrich Miller, Stefan Sommer and Bernhard Stauffer: Sulfate record from a northeast Greenland ice core over the last 1200 years based on continuous flow analysis

Gordon Hamilton and Ian Whillans, Measurements of local rates of ice sheet thickness change in Greenland

Maria Plougmann Hag, Håkon Gjessing Karlsen, Jørgen Bille-Hansen and Carl Egede Bøggild: Time trends in runoff and climatology from an ice-sheet margin catchment in West Greenland

Thursday, 23 August 2001

0840-0940h

CHAIR: Hans Oerter

Session 8: High-Resolution Analysis and Time-Sgales: Dating and Phasing

Jørgen Peder Steffensen, Jakob Schwander, Sören Wedel Nielsen and Josef Kipfstuhl: Do cloudy bands in ice cores always represent chemical stratigraphy?

Eric J. Steig and Richard B. Alley: Phase relationships between Antarctic and Greenland climate records

Pieter M. Grootes and Marie-Josée Nadeau: The Taylor Dome time scale and global climate synchrony

$1000-1410 h$

CHAIR: Hans Röthlisberger

\section{SESSION 9: Physias AND Flow}

JérômeWeiss, J.Vidot, Michel Gay, Laurent Arnaud, Paul Duval and Jean Robert Petit: Dome Concordia ice microstructure: impurities effect on grain growth

Piers R. F. Barnes, Heidy M. Mader, Regine Röthlisberger, Roberto Udisti and Eric W. Wolff: The evolution of chemical peak shapes in the Dome $\mathrm{C}$ ice core, Antarctica

Ian Baker and Daniel Cullen: The structure and chemistry of $94 \mathrm{~m}$ Greenland Ice Sheet Project 2 ice

Yun Wang, Thorsteinn Thorsteinsson, Josef Kipfstuhl, Heinz Miller, Dorthe Dahl-Jensen and Hitoshi Shoji: A vertical girdle fabric in the NorthGRIP deep ice core, North Greenland

Atsushi Miyamoto, Hitoshi Shoji and Okitsugu Watanabe: Uniaxial compression tests of cloudy band ice specimens from the GRIP, Greenland ice core 
D. Dahl-Jensen, T. Thorsteinsson, A. Svensson and Y. Wang: Anisotropic models based on the observed ice crystal fabric at NorthGRIP

Throstur Thorsteinsson and Edwin D. Waddington: Folding in strongly anisotropic layers near ice-sheet centers

Véronique Verbeke, Reginald Lorrain, Sigfús Johnsen and Jean-Louis Tison: A multiple step deformation history of basal ice from the Dye 3 (Greenland) core: new insights from the $\mathrm{CO}_{2}$ and $\mathrm{CH}_{4}$ content

$1410-1710 \mathrm{~h}$

CHAIR: Edwin D. Waddington

\section{Session 10: The Future: New Methods, New Cores, New Ideas}

J.-M. Barnola, C. Goujon, C. Coléou, E. Boller and P. Duval: First 3-dimensional study of the firn-ice transition by X-ray tomography

F. Nakazawa, N. Harada, K. Ohta, M. Nakawo, K. Fujita, Y. Ageta and N. Takeuchi: The potential use of amino acids as an indicator for micro-organism production in ice core analysis

Diedrich Fritzsche, Frank Wilhelms, Lev M. Savatyugin, Jean Francis Pinglot, Hanno Meyer, Hans-Wolfgang Hubberten and Heinz Miller: A new deep ice core from Akademii Nauk ice cap, Severnaya Zemlya, Eurasian Arctic: first results

R. van Trigt, Harro A. J. Meijer, Arny E. Sveinbjörnsdóttir, Sigfús J. Johnsen and Erik R. Th. Kerstel: Measuring stable isotopes of hydrogen and oxygen in ice by means of laser spectrometry: the Bølling transition in the Dye-3 ice core

David L. Morse, Donald D. Blankenship, Edwin D. Waddington and Thomas A. Neumann: A site for deep ice coring in West Antarctica: results from aerogeophysical surveys and thermo-kinematic modeling

Ryan Bay and P. Buford Price: Optical logging for dust and microbes

Jeffrey Severinghaus, James White, Kendrick Taylor, Edward Brook and Richard Alley: Gas-isotope evidence for abrupt climate change in Antarctica 19 and 15 kyr BP

Kurt Cuffey, Jeff Kavanaugh and Françoise Vimeux: Analyses of a source temperature-corrected Antarctic temperature history

$1710-1800 \mathrm{~h}$

CHAIR: Eric W. Wolff

Discussion: Ice cores and climate - the next ten years 